\title{
KAJIAN TEKSTUAL TARI DAMPENG AYOHOK DI DESA KILANGAN KECAMATAN SINGKIL KABUPATEN ACEH SINGKIL
}

\author{
Salisna Oktari ${ }^{1}$, Dillinar Adlin ${ }^{2}$ \\ Program Studi Pendidikan Tari, Fakultas Bahasa dan Seni,Universitas Negeri Medan \\ Jalan Willem Iskandar Pasar V Medan Estate 20221, Sumatera Utara-Indonesia \\ Email: ${ }^{1}$ Oktarisalisna13@gmail.com,${ }^{2}$ dilinaradlinmpd@gmail.com
}

\begin{abstract}
This study aims to describe how the Textual Study of Dampeng Ayohok Dance in Kilangan Village, Singkil District, Aceh Singkil District. The theoretical foundation in this paper is used as a guideline in data collection consisting of textual studies and Dampeng dance which are used as references in conducting this research. The theory used to discuss this research is the theory of textual study by $\mathrm{Y}$. Sumandiyo Hadi. Textual studies see Dampeng dance from the choreographic analysis side of choreographic analysis consisting of unity, repetition or repetition, transition or displacement and sequence. Structural analysis consisting of patterns and various motions. Symbolic analysis (tagging system).The method used by the author in collecting data is by observation, interviews, literature studies and documentation. Observations carried out such as the form of Dampeng dance, recording the results of interviews and carrying out video and photo documentation. Continued to review each Textual consisting of motion form analysis, Structural Analysis and Symbolic Analysis on Dampeng dance in accordance with the theory used. These data are then analyzed by Qualitative Descriptive Methods. The results of this study in terms of choreographical analysis on Dampeng Ayohok dance are analyzed from the form of motion where Dampeng dance consists of eight forms of opening greetings, clapping, mekhe salam, kisar (rotating), standby, holding dakhilebe (parrying from the front), installing steps and rubbing (closing). Structural analysis consists of patterns of motion and range of motion. The pattern of motion in dance is accompanied by a circle pattern and consists of four different forms of motion. Symbolic analysis consists of marking on motion, setting, floor pattern, and poetry.
\end{abstract}

Keywords: Dampeng, Tekstual dance, Aceh Singkil

\begin{abstract}
ABSTRAK
Penelitian ini bertujuan untuk mendeskripsikan bagaimana Kajian Tekstual tari dampeng ayohok Di Desa Kilangan Kecamatan Singkil Kabupaten Aceh Singkil. Landasan teoritis dalam skripsi ini dijadikan pedoman dalam pengumpulan data terdiri dari kajian tekstual dan tari dampeng ayohok yang dijadikan acuan dalam melakukan penelelitian ini. Teori yang digunakan untuk membahas penelitian ini yaitu teori tentang kajian tekstual oleh Y. Sumandiyo Hadi. Kajian tekstual melihat tari Dampeng dari sisi analisis koreografis analisis koreografi yang terdiri atas kesatuan atau unity, repetisi atau pengulangan, transisi atau perpindahan dan rangkaian. Analisis struktur yang terdiri dari pola-pola dan ragam gerak. Analisis simbolik (sistem penandaan). Metode yang digunakan penulis dalam mengumpulkan data yaitu dengan cara observasi, wawancara, studi kepustakaan dan dokumentasi. Observasi yang dilakukan seperti bentuk tari dampeng, merekam hasil wawancara dan melakukan dokumentasi video dan foto. Dilanjutkan mengkaji setiap Tekstual yang terdiri atas analisis bentuk gerak, Analisis struktural dan analisis simbolik pada tari dampeng sesuai dengan teori yang digunakan. Data-data ini kemudian dianalisis dengan Metode Deskriptif Kualitatif. Hasil penelitian ini dari sisi analisis koreografis pada tari dampeng ayohok dianalisis dari bentuk gerak dimana tari dampeng ayohok terdiri atas delapan bentuk gerak salam pembuka, bertepuk, mekhe salam, kisar (memutar), siaga, menahan dakhilebe (menangkis dari depan), memasang langkah dan membekhesalam (salam penutup). Analisis struktural terdiri atas pola-pola gerak dan ragam gerak. Pola gerak dalam tari
\end{abstract}


dampeng yaitu pola lingkaran dan terdiri atas empat bentuk ragam gerak. Analisis simbolik terdiri dari penandaan pada gerak, setting, pola lantai, dan syair.

Kata kunci : Tari Dampeng, Tekstual, Aceh Singkil

\section{PENDAHULUAN}

Provinsi Aceh merupakan salah satu Provinsi yang ada di Indonesia tepatnya berada dibagian paling ujung utara pulau Sumatera. Provinsi Aceh terbagi atas beberapa wilayah yakni Aceh Barat dengan Ibu Kota Meulaboh, Aceh Barat Daya dengan Ibu Kota Blang Pidie, Aceh Besar dengan Ibu Kota Jantho, Aceh Jaya dengan Ibu Kota Calang, Aceh Selatan dengan Ibu Kota Tapak Tuan, Aceh Singkil dengan Ibu Kota Singkil, Aceh Tamiang dengan Ibu Kota Karang Baru, Aceh Tengah dengan Ibu Kota Takengon, Aceh Tenggara dengan Ibu Kota Kuta Cane, Aceh Timur dengan Ibu Kota Idi Rayeuk, Aceh Utara dengan Ibu Kota Lhoksukon, Bener Meriah dengan Ibu Kota Simpang Tiga Redelong, Bireuen dengan Ibu Kota Bireuen, Gayo Lues dengan Ibu Kota Blang Kejeren, Nagan Raya dengan Ibu Kota Suka Makmue, Pidie dengan Ibu Kota Sigli, Pidie Jaya dengan Ibu Kota Meureudu, dan Simeulue dangan Ibu Kota Sinabang.

Salah satu Kabupaten yang ada di Provinsi Aceh adalah Kabupaten Aceh Singkil. Kabupaten Aceh Singkil merupakan pemekaran dari Kabupaten Aceh Selatan dan sebagian wilayahnya berada di kawasan Taman Nasional Gunung Leuser. Kabupaten ini juga terdiri dari dua wilayah, yakni Daratan dan Kepulauan. Kepulauan yang menjadi bagian dari Kabupaten Aceh Singkil adalah Kepulauan
Banyak. Ibu Kota Kabupaten Aceh Singkil terletak di Singkil.

Penduduk asli Kabupaten Aceh Singkil adalah Suku Singkil, Aneuk Jamee dan Haloban. Namun di Singkil terdapat suku pendatang diantaranya seperti suku Aceh, Minang dan Pakpak. Masyarakat dalam wilayah Kabupaten Aceh Singkil secara garis besar dapat dikelompokkan berdasarkan asalusulnya, walaupun sekarang ini sudah samar. Beberapa etnis asli dan etnis pendatang yang menetap di wilayah Singkil diantaranya seperti Etnis Aceh, Etnis Batak, Etnis Minangkabau, Etnis Nias, dan Etnis-etnis lainnya dalam jumlah kecil. Adapun seni tari atau jenis tarian yang ada di Singkil yang sering dipertunjukan oleh masyarakat diantaranya tari dampeng ayohok, tari dampeng iyola, tari alas, tari bharat, tari sri ndayong, tari piring, tari biahat (tari Harimau), tari payung, dan tari lelambe.

Tari dampeng ayohok telah ada sejak tahun 1986. Penelitian mengenai tari dampeng pernah dilakukan oleh Fira Ramayunika pada tahun 2016 yang hanya menjelaskan bentuk penyajian, gerak tari dampeng, pola lantai, tata busana penari, dan iringan musik namun didalam penelitian ini gerak tari dampeng tidak detail sampai pada rincian ragam gerak. tari dampeng ayohok adalah tarian yang tumbuh dan berkembang di Aceh Singkil. Masyarakat Aceh Singkil masih mempertunjukan dan 
memberdayakan tari dampeng ayohok untuk menjaga keberadaannya. Hal ini yang penulis lakukan dari matakuliah Kajian Mandiri tahun 2018. Tari ini merupakan tari penyambutan yang ditampilkan atau dipertunjukan pada acara-acara tertentu seperti pesta pernikahan, sunat rasul, serta menyambut tamu kehormatan. Penelitian mengenai tari Dampeng sebelumnya sudah ada diteliti di Desa Bukit Harapan oleh Linda Novalia Sihotang pada tahun 2015. Peneliti terkait tari Dampeng pernah dilakukan oleh Linda yang berkaitan degan fungsi tari dampeng. Tari dampeng diartikan pembukaan seiring berkembangnya zaman tari ini banyak digunakan dalam pertunjukan, serta pesta perkawinan, khitanan, penyambutan tamu dan sebagainya. Maka dapat disimpulkan bahwa tari dampeng ayohok memanglah tarian yang ditampilkan atau disajikan pada saat beberapa acara salah satunya dalam acara pernikahan.

Tari dampeng memiliki nilai yang tinggi dan nilai yang sangat baik bagi masyarakat Aceh Singkil dan masyarakat merasa bahwa tari dampeng Aceh Singkil sebagai dari seni dan pelestarian budaya yang masih ada dan masih dikenal masyarakat Aceh Singkil. Menurut Bapak Baharuddin yang merupakan narasumber serta salah satu guru tari dampeng ayohok yang ikut menjaga, melestarikan serta memberdayakan tari dampeng ayohok di Aceh Singkil. Beliau juga menjelaskan bahwa seluruh ilmu mengenai tari dampeng ayohok ia dapatkan sejak tahun 1960 diberikan oleh gurunya diantara guru-guru tersebut ialah Almarhum. Taktuan, Almarhum. Kandar dan Almarhum. Panglima Dogor.
Pada awalnya tari dampeng ayohok ini ditarikan oleh laki-laki saja yang melakukan gerakan silat berlawanan dengan pukulanpukulan yang lumayan keras namun seiring berkembangnya zaman tari dampeng ayohok dapat ditarikan oleh laki-laki dan perempuan. Tari dampeng ayohok dilakukan secara berkelompok dan dimainkan oleh penari yang berjumlah genap biasanya 8 (delapan) hingga 12 (dua belas) orang penari.

Alat musik yang digunakan dalam tarian ini masih menggunakan alat musik tradisional seperti gendang dua wawah, rapai, rebana, canang kayu dan dibantu dengan alat musik talam dan botol. Tarian dampeng ayohok ditampilkan sembari melantunkan pantunpantun nasehat yang menggunakan bahasa Aceh Singkil. Pantun-pantun nasehat tersebut terdiri atas beberapa syair. Makna yang terkandung dari petikan syair tersebut adalah untuk mengingatkan kepada saudara-saudara agar ajaran dalam syair dapat dijadikan pelajaran atau ditaati.

Dari pemaparan diatas penulis ingin melakukan penelitian dengan judul "Kajian Tekstual Tari dampeng ayohok di Desa Kilangan Kecamatan Singkil Kabupaten Aceh Singkil". Dalam segi pengkajian secara Tekstual penulis melakukan analisis koreografi yang terdiri atas kesatuan atau unity, repetisi atau pengulangan, transisi atau perpindahan dan rangkaian. Analisis struktur yang terdiri dari pola-pola dan ragam gerak. Analisis simbolik (makna).

Teori yang dipakai dalam penelitian ini adalah teori dari Y Sumandiyo Hadi (2007:23) : "Kajian tekstual artinya fenomena tari 
dipandang sebagai bentuk fisik (teks) yang relatif berdiri sendiri, yang dapat dibaca, ditelaah, dianalisis secara tekstual atau menteks sesuai dengan konsep pemahamannya".

Lokasi penelitian di Desa Kilangan Kecamatan Singkil Kabupaten Aceh Singkil, Provinsi Aceh. Lokasi ini dipilih menjadi lokasi penelitian karena tari dampeng ayohok masih terjaga dan masih terus dipertunjukan di beberapa tempat di Kabupaten Aceh Singkil. Waktu Penelitian ini dilakukan sejak Agustus 2018 sampai dengan November 2018.

Populasi yang akan diteliti dalam penelitian ini adalah para seniman tari dampeng ayohok yang berjumlah 12. Sampel dalam penelitian ini adalah 12 orang dari jumlah seniman Tari dampeng. Teknik Pengumpulan Data yang dilakukan adalah sebagai berikut: 1 . Kepustakaan, 2. Observasi, 3. Wawancara, 4. Dokumentasi.

Untuk menghindari kesulitan dalam analisis data maka penulis mengumpulkan seluruh informasi dan data-data dari kepustakaan, wawancara, observasi dan dokumentasi dikumpulkan, maka penulis menganalisa dan menguraikan data-data tersebut dengan menggunakan teknik deskriptif kualitatif sebagai prosedur pemecahan masalah yang diselidiki dengan menggambarkan keadaan objek penelitian pada saat sekarang. Data dan fakta yang dikumpulkan harus diolah dan ditafsirkan. Hal ini dilakukan agar hasil penelitian dapat dipercaya dan dipertanggung jawabkan. Analisis data juga meliputi untuk memeriksa kembali data-data yang masuk dari hasil penelitian yang nantinya akan menjadi bentuk skripsi.

\section{HASIL DAN PEMBAHASAN.}

\section{Tari dampeng ayohok Desa Kilangan} Kecamatan Singkil Kabupaten Aceh Singkil. Tari dampeng ayohok merupakan salah satu tari tradisional Aceh Singkil. Tari ini merupakan tari penyambutan yang ditampilkan atau dipertunjukan pada acara-acara tertentu seperti pesta pernikahan, sunat rasul, serta menyambut tamu kehormatan. Tari dampeng ayohok ini ditarikan oleh penari pria dan penari wanita (muda-mudi). Tari dampeng ayohok biasanya dimainkan oleh 8 hingga 12 orang penari.

Tari dampeng ayohok merupakan tari berkelompok. Ciri khas dari tari dampeng ayohok ini yakni gerakan-gerakan silat, dalam penyajian tari dampeng ayohok pertama sekali memberikan salam penghormatan kepada tamu, kemudian penari melirik keluar dan selanjutnya menghentakkan kaki secara serentak dengan maksud untuk bersiap siaga.

Musik pengiring merupakan salah satu unsur pendukung dalam tarian. Musik juga berfungsi sebagai alat pengatur tempo yang memberikan suasana pada suatu tarian. Musik iringan dalam tari dampeng ayohok ini dimainkan dari awal tarian sampai tarian itu selesai dengan menggunakan syair yang dilantunkan secara bersamaan dengan musik yang dimainkan. Adapun alat musik yang digunakan dalam tari dampeng ayohok ini adalah alat musik tradisional Aceh Singkil seperti rapai, canang kayu, gendang dua wawah.

Sumber iringan vokal pada tarian dampeng ayohok yaitu melantunkan pantunpantun nasehat yang menggunakan bahasa Aceh Singkil oleh penghulu konde (penyair). 
Pantun-pantun nasehat tersebut terdiri atas beberapa syair. Pantun dan syair dalam tari dampeng ayohok ini dimainkan sesuai dengan kondisi maupun suasana.

Busana penari pria pada tari dampeng ayohok di Desa Kilangan Kecamatan Singkil Kabupaten Aceh Singkil menggunakan topi yang disebut peci atau kupiah, baju kemeja panjang, celana panjang dan menggunakan kain songket yang disebut dengan kain sarung bekilat yang diikatkan dipinggang. Pada riasan wajah, penari pria tidak menggunakan riasan wajah, penari pria menampilkan tari dampeng ayohok tanpa menggunakan riasan wajah sedikitpun.

Busana penari wanita pada tari dampeng ayohok di Desa Kilangan Kecamatan Singkil Kabupaten Aceh Singkil menggunakan penutup kepala atau jilbab, baju kurung panjang, celana panjang yang menggunakan kain songket yang disebut dengan kain sarung bekilat yang diikatkan dipinggang dan tali pinggang yang dipakai penari disebut banjing. Berbeda dengan penari pria, penari wanita menggunakan riasan wajah, rias wajah yang digunakan penari wanita tari dampeng ayohok adalah rias cantik yang menggunakan warna cerah yang bertujuan untuk mempercantik penampilan penari wanita.

Sunting disebut daerah pesisir dibuat dari kertas untuk penari dampeng ayohok. Nama lain dari sunting yaitu nakan gersing didaerah pesisir. Nakan gersing memiliki arti makan nasi kunyit pulut. Sunting di pesisir atau beras pulut maknanya nasi kunyit merupakan oleh-oleh yang diberikan kepada raja yang akan dibagikan kepada penari, pada Tari dampeng ayohok yang ditarikan sebelum subuh. Di sunting terdapat bunga yang diletakkan di atas beras pulut, bunga terdiri dari beberapa warna.

\section{Kajian Tekstual Tari dampeng ayohok di Desa Kilangan Kecamatan Singkil Kabupaten Aceh Singkil.}

Dalam menganalisis tari dampeng ayohok secara tekstual, penulis membuat data pengelompokan yang berdasarkan analisis koreografi yang terdiri atas kesatuan atau unity, repetisi atau pengulangan, transisi atau perpindahan dan rangkaian. Analisis struktur yang terdiri dari pola-pola dan ragam gerak. Analisis simbolik (sistem penandaan atau makna).

\section{Analisis Koreografi Tari dampeng ayohok.}

\section{Kesatuan atau Unity}

Kesatuan mengandung pengertian seluruh aspek-aspek gerak yang dipadukan menjadi satu bentuk yang utuh. Dalam tari dampeng ayohok ini bentuk keseluruhannya secara utuh terdiri dari ragam gerak yang disatukan menjadi kesatuan yang utuh. Gerak tersebut terdiri dari pembuka yaitu bertanda untuk memulai suatu tarian yang akan dimainkan, bertepuk yaitu sebagai sebuah kode untuk penari bahwa mereka bersiap dalam menyambut raja, mekhesalam (salam pembuka) yang artinya pemberian rasa hormat kepada raja atau tamu yang dihormati, salam jika dikaitkan dalam agama Islam salam berarti menyampaikan pesan damai atau doa, gerakan kisar (memutar) yang artinya gerakan yang bermakna untuk menjauh atau menghindari lawan dari serangan musuh, siaga yang artinya 
siap mempertahankan diri dari serangan lawn untuk menjaga raja, menahan dakhilebe (menangkis dari depan) yang artinya pembelaan diri terhadap lawan ketika musuh menyerang, memasang langkah yang artinya mempersilahkan atau bersiap menerima serangan dari lawan dan membekhesalam (salam penutup) yang artinya memberikan isyarat penghormatan dan salam terhadap lawan bahwa berakhirnya suatu pertarungan.

\section{Repetisi atau Pengulangan}

Repetisi atau pengulangan dilakukan untuk lebih menampakan kekhasan bentuk gerak sehingga menjadi ciri khas sajian sebuah bentuk tari. Beberapa gerakan yang terjadi pengulangan adalah gerak kisar, dalam gerakan ini terjadi pengulangan karena penari menahan diri dari serangan musuh, gerak siaga gerakan ini terjadi pengulangan karena pada saat melakukan gerakan ini penari melakukan gerakan mempertahankan diri dari serangan lawan. Menangkis dari depan terjadi pengulangan dikarenakan seorang penari (prajurit) melakukan pembelaan diri terhadap serangan lawan. Memasang langkah terjadi pengulangan dikarenakan penari bersiap untuk menerima serangan lawan. Dari penjelasan tersebut, dalam tari dampeng ayohok terdapat pengulangan gerakan yang dilakukan dengan jumlah pengulangan yang cukup banyak.

\section{Transisi atau Perpindahan.}

Analisis terhadap transisi merupakan perpindahan-perpindahan atau sambungan dari gerak yang satu dan gerak yang lain dengan lancar dan terampil. Motif gerak transisi tidak dapat berdiri sendiri tetapi harus menyatu dalam kesatuan motif-motif gerak yang akan disambung. Bentuk gerak transisi atau perpindahan yang terdapat dalam tari dampeng ayohok yaitu gerak memasang langkah. Memasang langkah menjadi gerak transisi dikarenakan memasang langkah dilakukan untuk memulai penyerangan terhadap musuh. Gerakan memasang langkah dilakukan dengan cara menunduk dan melihat kebawah, meletakan tangan kanan lurus kebawah dan tangan kiri berada dibawah pinggang, dengan posisi kaki sedikit mendak dan posisi kaki kiri berada didepan dan posisi kaki kanan berada dibelakang. Gerakan ini dilakukan dalam setiap pergantian ragam gerak yang satu ke ragam gerak selanjutnya.

\section{Rangkaian}

Rangkaian dalam analisis bentuk gerak merupakan bagian-bagian bentuk gerak yang dirangkai atau disusun sehingga dapat disimpulkan secara bersama. Tari dampeng ayohok terdiri dari delapan rangkaian gerak bertepuk membuka yaitu rangkaian gerak menepuk tangan untuk memulai tarian, mekhe salam (salam pembuka) yaitu rangkaian gerak yang dilakukan untuk menghormati penonton, Kisar (memutar) yaitu gerak yang dilakukan dengan berputar ditempat untuk melihat musuh yang ada disekeliling, siaga yaitu gerak menjaga diri dari serangan musuh yang akan datang, Menahan dakhilebe (menangkis dari depan) yaitu gerakan mempertahankan diri saat menghadap musuh, memasang langkah yaitu gerakan yang dilakukan untuk memulai melawan musuh, Membekhe Salam (salam 
penutup) yaitu gerakan yang dilakukan untuk menghormati penonton.

\section{Analisis Struktural}

\section{Pola Lantai}

Keseluruhan tari dampeng ayohok dari awal tarian hingga akhir tarian menggunakan pola lingkaran. Namun pola lingkaran ini para penari tidak selalu berada ditempat dikarenakan penari saling berganti posisi membentuk pola lingkaran. Pola lingkaran yang pertama, diawali dengan pola lantai lurus dengan saling menghaap depan. Pola lantai ini sebagai intro masuk dalam tari dampeng ayohok. Pola lantai kedua, berproses membentuk pola lingkaran dengan arah hadap membelangkai sunting yang berada di tengah lingkaran, pola lantai ini untuk berjaga-jaga dari serangan musuh. Pola lantai ketiga, yang berbentuk lingkaran ini menghadap arah kiri dengan melakukan gerakan silat untuk melindungi raja dari serangan lawan. Pola keempat ini berbentuk lingkaran dengan menghadap arah depan dengan posisi penari bersimpuh, yang artinya bahwa prajurit atau masyarakat benar-benar menghormati raja dan taat kepadanya.

\section{Ragam Gerak}

Tari dampeng ayohok ini terdiri dari delapan bentuk gerak yaitu bertepuk membuka yaitu rangkaian gerak menepuk tangan untuk memulai tarian, mekhe salam (salam pembuka) yaitu rangkaian gerak yang dilakukan untuk menghormati penonton, Kisar (memutar) yaitu gerak yang dilakukan dengan berputar ditempat untuk melihat musuh yang ada disekeliling, Siaga yaitu gerak menjaga diri dari serangan musuh yang akan datang, menahan dakhilebe (menangkis dari depan) yaitu gerakan untuk mempertahankan diri ketika menghadap serangan dari musuh, dengan memasang langkah dan gerak-gerik dalam pola gerakan yang dilakukan untuk memulai melawan musuh, Membekhe Salam (salam penutup) yaitu gerakan yang dilakukan untuk menghormati penonton.

\section{Analisis Simbolik}

Tari dampeng ayohok merupakan salah satu media untuk memberikan pesan atau nasehat yang mencerminkan pendidikan, keagamaan, sopan santun, kepahlawanan, kekompakan dan kebersamaan. Awal mula tari dampeng ayohok ini melingkar dan mengelilingi dengan arah tangan kiri ke tengah yang bermakna mempertahankan posisi atau melindungi dari serangan musuh. Analisis simbolik pada tari dampeng ayohok dilihat dari sistem penandaanya yaitu bertepuk membuka yaitu rangkaian gerak menepuk tangan untuk memulai tarian, mekhe salam (salam pembuka) yaitu rangkaian gerak yang dilakukan untuk menghormati penonton, Kisar (memutar) yaitu gerak yang dilakukan dengan berputar ditempat untuk melihat musuh yang ada disekeliling, siaga yaitu gerak menjaga diri dari serangan musuh yang akan datang, menahan dakhilebe (menangkis dari depan) yaitu gerakan mempertahankan diri saat menghadapi musuh, memasang langkah yaitu teknik gerakan yang akan dilakukan untuk memulai melawan musuh, membeke $s$ alam (salam penutup) yaitu pola gerakan yang dilakukan untuk menghormati 
penonton. Sistem penandaan pada tari dampeng ayohok dilihat dari empat sisi yang terdiri dari makna yang dilihat dari gerak, makna dilihat dari setting maupun pola lantai dan dari makna dilihat dari syair.

\section{Makna Dilihat Dari Setting}

Sunting digunakan sebagai setting tidak bergerak pada tari dampeng ayohok yang berisikan beberapa warna dan beras pulut. Pada zaman dahulu, beras yang disajikan akan diberikan raja (pemuka adat) kepada para penari tari dampeng ayohok setelah tarian selesai ditampilkan. Hal ini menandakan adanya penghormatan raja (pemuka adat) terhadap orang yang menarikan tari dampeng ayohok. Makna warna bunga yang diletakan di atas beras pulut yaitu merah sebagai keberanian, kuning sebagai kerajaan atau kepahlawanan, dan hijau artinya simbol agama Islam.

\section{Makna Dilihat dari Pola Lantai}

Tari dampeng ayohok secara keseluruhan menggunakan empat pola yaitu pola lingkaran. Dimana penari melakukan ragam gerak dengan pola lingkaran yang bervariasi seperti yang telah dijelaskan diatas. Pada dasarnya pola lingkaran ini merupakan pola yang telah ada atau pola yang telah ditetapkan pada awal munculnya tari dampeng ayohok ini. Makna dalam bentuk pola lingkaran ini adalah memberikan pengawalan atau penjagaan serta pengamanan terhadap seseorang yang berada di tengah pola lingkaran. Pada awal kemunculan tari dampeng ayohok, yang berada di tengah pola lingkaran tersebut adalah seorang raja, para penari melakukan tari dampeng ayohok dengan pola lingkaran sembari mengelilingi raja yang dimaknai memberikan penjagaan terhadap raja tersebut. Untuk saat ini yang berada ditengah pola lingkaran adalah sunting, dimana sunting tersebut mengibaratkan raja yang sedang berada ditengah penari yang sedang mempertunjukan tari dampeng ayohok.

\section{Makna Dilihat Dari Syair}

Syair yang digunakan untuk mengiringi tari dampeng ayohok menggunakan bahasa Aceh Singkil. Sebagian besar syair tersebut merupakan kalimat do'a yang dianut oleh umat beragama Islam seperti pada syair amalkanlah agama Islam dan jangan mensia-siakan agama. Syair tersebut menandakan bahwa sebagian besar masyarakat Singkil beragama Islam. Pada syair ya Allah ya Rahman sehatkan kami, sang pengiring atau pelantun syair mengingkinkan Allah SWT memberikan kekuatan hati untuk para peserta tari dampeng ayohok. Memberikan keimanan serta berkat dan syafaat nabi Muhammad junjungan terhadap kampung tempat tinggal. Kalimat-kalimat do'a ini menandakan bahwa para peserta tari dampeng ayohok beserta masyarakat Kabupaten Aceh Singkil taat beribadah dan memohon do'a hanya kepada Allah SWT.

Kalimat-kalimat tersebut juga mengandung pantun nasihat seperti kalimat jaga muda mu sebelum tua. Kalimat-kalimat ini menandakan adanya kepedulian antar sesama, pemberian nasihat antara yang tua kepada yang muda menandakan adanya sikap menjaga generasi muda. Kalimat pantun nasihat untuk sesama sepeti jangan sombong ingatlah dimasa 
miskin, ketika berada diatas (berpangkat) ingat kaum duafa dan jangan melupakan agama. Pantun ini menandakan adanya kepedulian antar sesama masyarakat.

\section{PENUTUP}

\section{A. Kesimpulan}

1. Analasis koreografis pada tari dampeng ayohok dilihat dari analisis koreografi yang terdiri atas kesatuan atau unity, repetisi atau pengulangan, transisi atau perpindahan dan rangkaian.

2. Analisis struktur yang terdiri dari pola-pola yang ada dalam keseluruhan tari dampeng ayohok dan ragam gerak pada tari dampeng ayohok yang terdiri atas empat ragam gerak.

3. Analisis simbolik terdiri dari penandaan pada gerak tari, penandaan pada setting tari, penandaan pada pola tari dan penandaan pada syair tari dampeng ayohok. Pada gerak tari menandakan tari dampeng ayohok ini merupakan tari perlindungan diri yang terdiri dari gerakan-gerakan silat. Pada pola tari dampeng ayohok yaitu sunting menandakan adanya penghormatan dan saling menghargai antara seseorang yang memiliki pangkat (raja) terhadap orang lain. Pada syair memberikan tanda bahwa tari dampeng ayohok adalah tari yang beraliran dan berlafaskan agama Islam dan menandakan adanya kepatuhan beragama dan saling menasihati antara satu sama lainnya.

\section{B. Saran}

Saran penulis adalah tari dampeng ayohok memiliki unsur filosofi yang cukup dalam memiliki unsur tekstual didalamnya, sehingga wajib untuk dijaga keasliannya baik dari segi sejarah maupun bentuk penyajiannya, karena tari dampeng ayohok ini merupakan bagian dari peninggalan budaya Aceh Singkil.

\section{DAFTAR PUSTAKA}

Arikunto, 2010. Metode Penelitian Kualitatif. Jakarta: Bumi Aksara.

Y. Sumandiyo Hadi, 2007. Kajian Tari Teks dan Konteks. Yogyakarta: Pustaka Book Publisher.

Purba Anna, 2014. Analisis Musikal Dan Tekstual Dampeng Pada Upacara Adat Perkawinan Suku Pesisir Di Kota Sibolga. Skripsi Universitas Sumatera Utara.

Linda Novalia Sihotang, 2015. Nilai Estetika Tari Dampeng Masyarakat Muara Pea Desar Bukit Harapan Kabupaten Aceh Singkil. E-Journal Universitas Negeri Medan.

Nurwani, 2015. Seni Dalam Perspektif Ilmu Sosial. Medan: Unimed Press.

Ramayunika Fira, 2016. Bentuk Penyajian Tari Dampeng Di Kampong Sakop Tanah Bara Kecamatan Gunung Meriah Kabupaten Aceh Singkil. E-Journal Unsyiah.

Ulimarina Kezia Purba, 2014. Analisis Musikal dan Tekstual Marsialopari Karya Taralamsyah Saragih. Skripsi Universitas Sumatera Utara.

Sugiono, 2009. Metode Penelitian Pendidikan. Bandung: Alfabeta.

$\begin{array}{crr}\text { Moleong, 2017. } & \text { Metodologi } & \text { Penelitian } \\ \text { Kualitatif. } & \text { Bandung: } & \text { Remaja } \\ \text { Rosdakarya } & \text { Bandung. } & \end{array}$

Pramutomo, 2007. Etnokoreologi Nusantara. Surakarta: ISI PRESS. 
Nathalia Nira, 2015. Kajian Tekstual The Drupadi Trilogy Karya Ananda Sukarlan. E-Journal Universitas Gadjah Mada. 